in our laboratory, ${ }^{5}$ to $50-100$ in others. ${ }^{27}$ Bearing in mind our laboratory cut off values, table 2 shows a logical demarcation between the positive and negative EIA and IHA subsets at a multiplicative quickscore $\geqslant 3$. Thirty six breast tumours with negative EIA results ( $\leqslant 9 \mathrm{fmoles} / \mathrm{mg}$ protein) occurred in the 0-2 quickscore subset; no oestrogen receptor negative breast tumours on EIA were reported in the 3-18 quickscore subset whereas 59 of 60 oestrogen receptor positive breast cancers were observed in this classification. Only one of 60 oestrogen receptor EIA positive tumours was present in the $0-2$ quickscore subset. The same results were obtained using a $\mathrm{H}$-score cut off $<20$. The one tumour negative on assessment using the quickscore but positive by IHA (Hscore $=32$ ) and oestrogen receptor-EIA (29 fmoles/mg protein) came from the same patient.

The results also show that there is no difference between adding or multiplying categories $\mathrm{A}$ and $\mathrm{B}$. The additive approach, with a range from 1 to 9, has two disadvantages. Firstly, the additive $(\mathrm{A}+\mathrm{B})$ quickscore does not permit a completely negative result, which occurred in many of our oestrogen receptor negative cases, whereas the multiplicative $(\mathrm{A} \times \mathrm{B})$ quickscore does. Secondly, the range is small for the additive quickscore. Considering the wide range of values within the quantitative methods, the multiplicative quickscore, ranging from 0 to 18 , is preferable. Without prejudicing accuracy, the quickscore approach takes about a quarter of the time taken when calculating the $\mathrm{H}$-score because it dispenses with the need to count individual cells.

G Saccani Jotti was supported in part by the following grants: CNR ACRO Project, CNR Bilateral 94.02482.CT04 and MURST $40 \%$ (Italy). SD and MD were supported by the Cancer Research Campaign.

1 Osborne CK. Receptors. In: Harris JR, Helman S, Henderson IC, Kinne DW, eds. Breast diseases. Philadelphia: JB Lippincott, 1991:301-25.

2 Andersen J. Determination of oestrogen receptors in paraffinembedded tissue. Acta Oncol 1992;31:611-27.

3 McClelland RA, Finlay P, Walker KJ, Nicholson D, Robertson JFR, Blamey RW, et al. Automated quantitation of immunocytochemically localised oestrogen receptors in human breast cancer. Cancer Res 1990;50:3545-50.

4 Barnes DM, Dublin EA, Fisher CI, Levison DA, Millis RR. Immunohistochemical detection of p53 protein in mammary carcinoma. Hum Pathol 1993;24:469-76.

5 Saccani Jotti G, Johnston SRD, Salter J, Detre S, Dowsett $M$. Comparison of a new immunohistochemical assay for oestrogen receptor in paraffin wax embedded breast caroestrogen receptor in parafin wax embedded breast car-
cinoma tissue with quantitative enzyme immunoassay. $\mathcal{I}$ Clin Pathol 1994;47:900-5.

6 Andersen J, Bentzen SM, Poulsen HS. Relationship between radioligand binding assay, immunoenzyme assay and immunohistochemical assay for oestrogen receptors in human breast cancer and association with tumour differentiation. Eur $\mathcal{F}$ Cancer 1988;24:377-84.

7 Kinsel B, Szabo E, Greene GL, Konrath J, Leight GS, McCarty KS. Immunocytochemical analysis of oestrogen receptors as a predictor of prognosis in breast cance patients: comparison with quantitative biochemical methods. Cancer Res 1989;49:1052-6. \author{
Esbjerg County
Hospital, \\ DK-6700 Esbjerg, \\ Denmark Department \\ of Internal Medicine \\ and Haematology \\ A Siboni \\ T Mourits-Anderson \\ Department of \\ Pathology \\ J Moesner \\ Correspondence to: \\ Dr Anders Siboni, \\ Skolebakken 66,4 ,th. \\ DK-6700 Esbjerg. \\ Denmark. \\ Accepted for publication \\ 1 December 1994
}

\title{
Granulomatous bone marrow inflammation during treatment of chronic myeloid leukaemia with interferon alpha-2b
}

\author{
A Siboni, T Mourits-Andersen, J Moesner
}

\begin{abstract}
A patient with chronic myeloid leukaemia developed bone marrow granulomas during treatment with interferon alpha-2b. Some granulomas had necrotic centres and giant cells and there was marked eosinophilia surrounding them. The granulomas disappeared when the interferon treatment was discontinued. Mycobacteriosis was ruled out. The most likely explanation for the granuloma formation was drug hypersensitivity.

(f Clin Pathol 1995;48:870-880)
\end{abstract}

Keywords: interferon, bone marrow granulomas.

The treatment of chronic myeloid leukaemia with interferon alpha-2b (IFN- $\alpha-2 b$ ) prolongs survival if cytogenic response occurs: in one study, partial cytogenetic response and temporary morphological remission was seen in $46 / 71$ patients. ${ }^{1}$ Interferon alpha is used in the treatment of both infectious and malignant diseases. ${ }^{2}$ One of its mechanisms of action may be inhibition of formation of new blood vessels (antiangiogenesis) in tumour areas. ${ }^{2}$

Bone marrow necrosis at blast transformation of chronic granulocytic leukaemia treated with interferon has been described by Kendra $e t ~ a l,{ }^{3}$ but the formation of bone marrow granulomas during the treatment of chronic myeloid leukaemia with IFN- $\alpha-2 b$ has not been described before.

\section{Case report}

A 43 year old man was referred in August 1992 because of a leucocyte count of $89 \times 10^{9} / 1$. Bone 


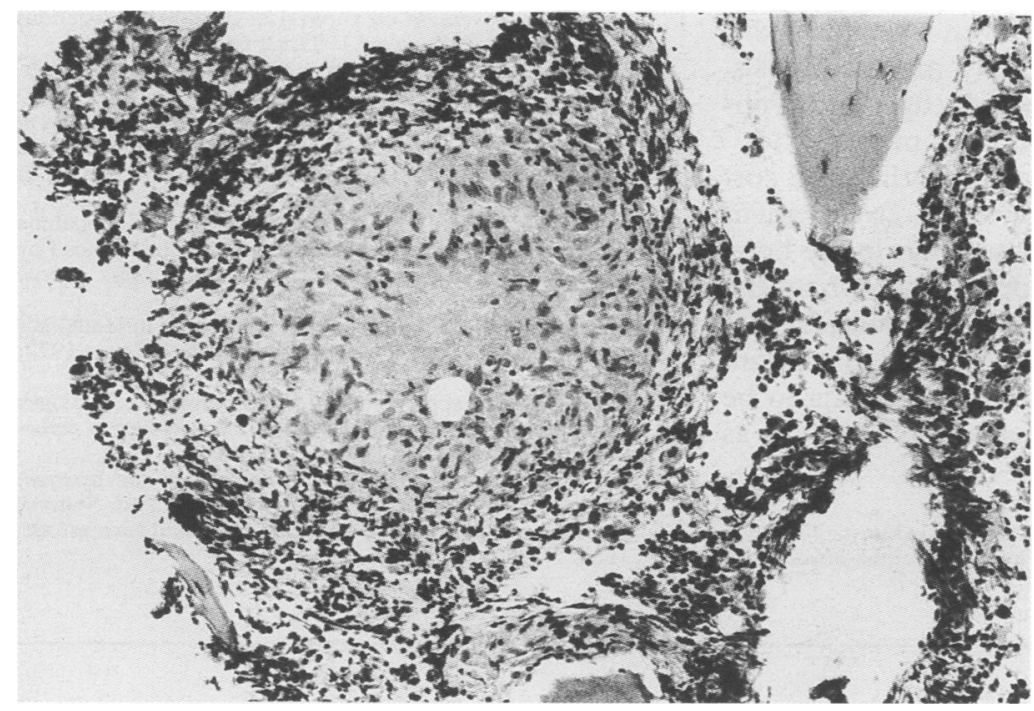

Figure 1 Bone marrow epithelioid cell granuloma with necrotic centre. Magnification $\times 33$.

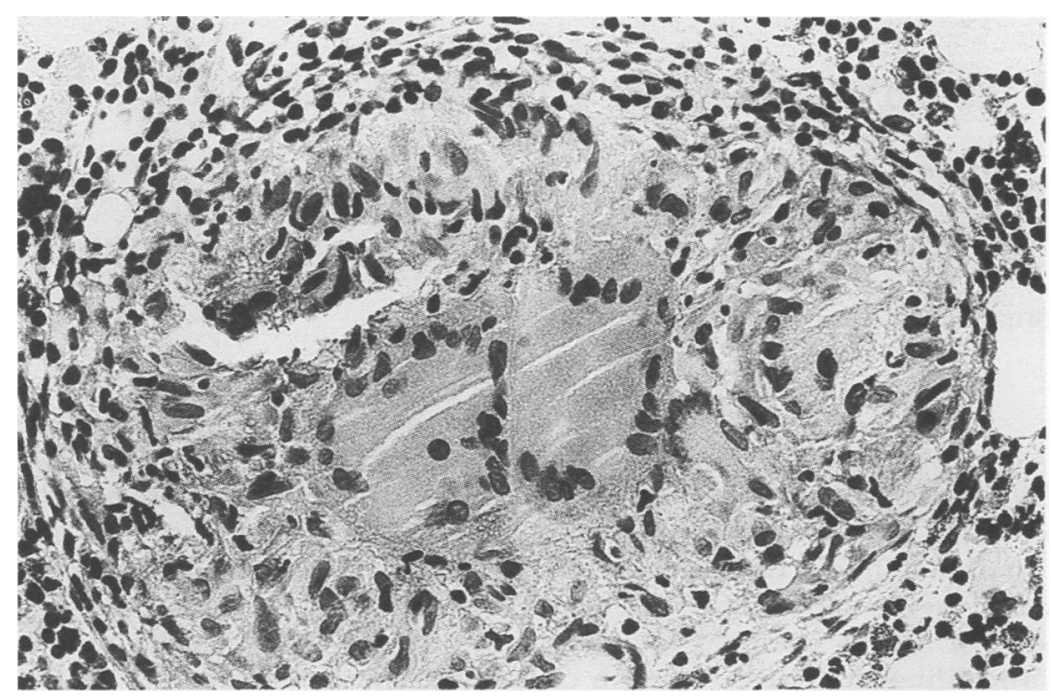

Figure 2 Bone marrow epithelioid cell granuloma with giant cells. Magnification $\times 82$.

marrow examination showed chronic myeloid leukaemia. Chromosome analysis of the same bone marrow showed 24/25 mitoses with 9;22 translocation (Philadelphia). Treatment with hydroxyurea $1.5 \mathrm{~g}$ daily and allopurinol $300 \mathrm{mg}$ daily was started. In November 1992, when the leucocyte count was reduced to about $5 \times 10^{9} / 1$, treatment with interferon alpha-2b (Intron $A$, Schering-Plough), 5 megaunits daily subcutaneously, was started and hydroxyurea was discontinued. During treatment with interferon there was a fine reddish exanthem on the chest and abdomen. The interferon dose was gradually increased to 8 megaunits daily (by March 1993) because of rising leucocyte counts. There were minor side effects of interferon such as pain in the left shoulder and the right gluteal region, and a sensation of warmth in the back of the neck.

Bone marrow biopsy in June 1993 showed chronic myeloid leukaemia in remission and, as a new finding, several epithelioid cell granulomas, some with necrotising centres (fig 1) and Langhans giant cells (fig 2). There was marked eosinophilia around the granulomas, but no mastocytosis. The eosinophil count in the blood was $0 \cdot 1 \times 10^{9} / 1$ and the basophil count was $0.5 \times 10^{9} / 1$. Cytogenetic analysis showed 23/25 cells with the $9 ; 22$ translocation. In July 1993 the bone marrow biopsy was repeated, with the same histological result. The Mantoux reaction was positive (the patient was BCG vaccinated as a child). The chest $x$ ray showed minor patchy infiltrations in the lungs. Antituberculous chemotherapy with isoniazid, rifampicin, ethambutol, and pyrazinamide was started on July 9 . Serum angiotensin converting enzyme was within normal limits and serum antibodies against the cytoplasm of polymorphonuclear leucocytes (ANCA) were not present.

Cultivation of bone marrow, urine, and expectorates from July 1993 showed no growth of mycobacteria. In October 1993 ethambutol and pyrazinamide were discontinued. Bone marrow biopsy in November 1993 still showed granulomas, some with central necrosis. The leucocyte count was $18.2 \times 10^{9} / 1$, the eosinophil count $0.2 \times 10^{9} / 1$, and the basophil count $1.8 \times 10^{9} / 1$. Culture of the same bone marrow for mycobacteria was negative. The chest $x$ ray was unchanged. Early in January 1994 isoniazid and rifampicin were discontinued. On January 12 interferon was discontinued and hydroxyurea was restarted at $2 \mathrm{~g}$ daily. Bone marrow biopsy in February 1994, examined in the Rigshospitalet in Copenhagen, showed no granulomas or blast foci. The chest $x$ ray had become normal. Bone marrow transplantation was performed in March 1993.

\section{Discussion}

Experimental studies with mice show that interferon gamma plays an essential role in granuloma formation after injection of glycolipid containing mycolic acid. ${ }^{4}$ The role of interferon gamma seems to be to stimulate the macrophages into forming granuloma epitheloid cells. ${ }^{4}$ All interferons can increase the expression of class I major histocompatibility complex, although the magnitude of change is greatest for interferon gamma. ${ }^{2}$ Interferon alpha is not known to promote granuloma formation.

Sarcoid reactions and sarcoidosis may occur in Hodgkin disease and other malignant lymphomas, ${ }^{5}$ but have not been described in chronic myeloid leukaemia. In the case described here the general appearance was that of sarcoid granulomas, some being of the tuberculoid type with necrotic centres (fig 1) and giant cells (fig 2). The surrounding eosinophilic areas were like eosinophilic fibrohistiocytic lesions, ${ }^{6}$ but the granuloma cells were more histiocytic than fibroblast-like and there was no mastocytosis in the bone marrow.

The patient had minor side effects such as an exanthem and pain, and a drug hypersensitivity reaction is a possible explanation of these symptoms. Drug hypersensitivity may also cause bone marrow granulomas. ${ }^{7}$ Peripheral blood eosinophilic counts, however, were not raised at any time.

Some infections which may cause bone marrow granulomas, ${ }^{7}$ such as brucellosis, leprosy, 
syphilis, leishmaniasis, $\mathrm{Q}$ fever, toxoplasmosis, cryptococcosis, infectious mononucleosis, herpes zoster, legionnaires' disease, and typhoid fever, were not suspected clinically.

In conclusion we suggest that the time correlation between interferon alpha- $2 b$ treatment and the appearance of granulomas in the bone marrow, and their disappearance when the treatment had been discontinued, suggest that the interferon caused the granuloma formation. The histology of the granulomas seems to be most compatible with drug hypersensitivity, as mycobacteriosis was ruled out.

1 Kloke O, Niederle N, Qiu JY, Wandl U, Moritz T, NagelHiemke $\mathrm{M}$, et al. Impact of interferon alpha-induced cy- togenic improvement on survival in chronic myelogenous leukaemia. Br f Haematol 1993;83:399-403.

2 Dorr RT. Interferon-alpha in malignant and viral disease. Drugs 1993;45:177-221.

3 Kendra JR, Pickens S, Singh AK. Bone marrow necrosis at transformation of chronic granulocytic leukaemia treated with interferon. $f$ Clin Pathol 1992;45:830-1; Erratum in f Clin Pathol 1993;46:192.

4 Asano M, Nakane A, Minagawa T. Endogenous gamma interferon is essential in granuloma formation induced by interferon is essential in granuloma in mice. Infect Immun 1993;61:2872-8.

5 Brincker H. Sarcoid reactions and sarcoidosis in Hodgkin's disease and other malignant lymphomas. Br $\mathcal{F}$ Cancer 1972; 26:120.

6 Wittels B. Surgical pathology of bone marrow - core biopsy diagnosis. In: Bennington JL, ed. Major problems in pathology. Philadelphia: WB Saunders, 1985.

7 Bain BJ, Wickramasinghe SN. Pathology of the marrow: general considerations. In: Symmers W St C, ed. Systemic pathology, vol 2, 3rd ed. Edinburgh: Churchill Livingstone, 1986.

\author{
St Mary's \\ Hospital Medical \\ School and St Mary's \\ Hospital, South \\ Wharf Road, \\ London W2 1NY \\ Hepatology Group, \\ Department of \\ Medicine \\ J Niu \\ U Kumar \\ J Monjardino \\ H C Tomas \\ Department \\ of Histopathology \\ $\mathrm{R}$ Goldin \\ Department \\ of Surgery \\ D Rosin \\ Correspondence to: \\ Dr J Monjardino, \\ Department of \\ Medicine, QEQM \\ Wing, St Mary's \\ Hospital Medical \\ School, South \\ Wharf Road, \\ London W2 $1 \mathrm{NY}$ \\ Accepted for publication \\ 21 February 1995
}

virus is actively replicating in a liver bearing a tumour; second, whether it is replicating in the tumour tissue itself; and finally, whether the type of virus found in the tumour was genetically identical to that found in the surrounding non-tumorous parenchyma and in serum collected at the same time.

\section{Case report}

The patient was an Indonesian male, aged 56 years, with chronic active HCV hepatitis and cirrhosis possibly related to a blood transfusion for a bleeding peptic ulcer in 1976. Serum markers of previous hepatitis $A$ and $B$ infections were present (HAV IgG +, $\mathrm{HBsAg}-$, anti$\mathrm{HBsAg}+$, anti-HBcAg +, $\mathrm{HBeAg}-, \mathrm{HBV}$ DNA -). Anti-HCV antibodies were detected both by second generation enzyme linked immunosorbent assay (ELISA) and by recombinant immunoblot assay (RIBA) (antic22P ++++ , anti-c33c ++++ , anti-100$3 \mathrm{P}++++$, anti-NS5 ++++ ), and serum HCV RNA was detected by polymerase chain reaction (PCR) amplification. ${ }^{2}$ A hepatocellular carcinoma was diagnosed after computerised axial tomography was done to investigate the development of hepatosplenomegaly and ascites. The carcinoma was found to occupy mostly segment 8 of the right lobe. Laparotomy was carried out to resect the affected liver lobe but the procedure was abandoned because of dissemination of the tumour to the left lobe. From the specimens removed for histology at the time of surgery, tissue was made available for the present study. 